\title{
The characteristics of the child dragged into crime among university students
}

\section{Üniversite öğrrencilleri arasında suça sürüiklenen çocuk karakteristikleri}

\author{
Sadık Toprak ${ }^{1}$, IIllhan Çetim², Alli Yıldırım³ ${ }^{3}$ Murat Aksư ${ }^{4}$, Burak Güimüiş ${ }^{5}$
}

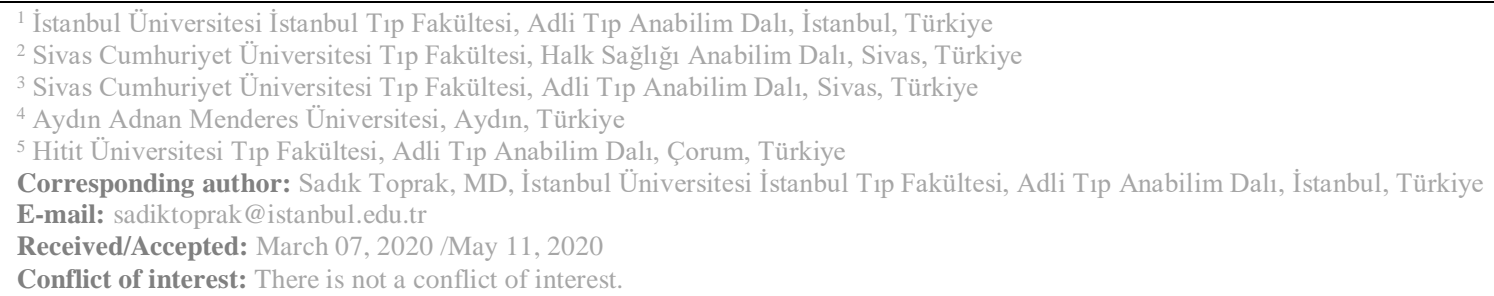

\section{SUMMARY}

Objective: Getting involved in crime in children is classified as a risktaking behaviour. Risk-taking behaviour is defined as a behaviour that creates proportionately the possibility of undesirable consequences. According to many studies, risk-taking behaviour and crime statistics reaches a peak during late adolescence and early adulthood. In our study, we aimed to search the prevalence of the crime behaviour and related factors in young adults dragged into the crime but somehow managed to receive university education.

Method: 706 university students from $1^{\text {st }}$ and $4^{\text {th }}$ grades were involved into this study.

Results: $15.3 \%$ of the participants state that they have committed a crime at least once; moreover, male gender is more frequently observed in children who are dragged into crime. The probability of being abused (physicalemotional-negligence) and self-harming behaviour are more common in children dragged into the crime.

Conclusions: The reason why most of the children dragged into crime are male; thus can be explained such factors as taking part of males ones in work and social life more, controlling and protection of females' spending time out of home. The frequency of getting involved into crime by those evaluating their income as inadequate is higher than the other group. Children living in a poor family, environment and privation may cause children to lead criminal and problematic behaviours. Self-harming behaviour is more common in children dragged into crime. Self-harming behaviour in lower-income people and in certain social groups has been observed more commonly; furthermore, it may be thought that what children dragged into crime live is related to the social environment and the levels of their income. As a result, it was found that children dragged into crime are the ones who are often males, belonging to the lower income group, having frequently self-harming behaviour; moreover, they are the children whose families have criminal past and they are the children who experience abuse more frequently. Child abuse, child neglecting and selfharming behaviour should be searched in all children who dragged into the crime.

Keywords: Child dragged into crime, child abuse, self-harming
Sadik Toprak
(D) İlhan Çetin
(I) Ali Yıldırım
(D) Murat Aksu
(D) Burak Gümüş

ORCID IDs of the authors: S.T. 0000-0002-8065-1334 İ.Ç. 0000-0001-9274-2113 A.Y. 0000-0002-4789-9805 M.A. 0000-0003-2429-4624 B.G. 0000-0002-2331-7196 
ÖZET

Amaç: Çocuklarda suça karışma, risk alıcı davranış olarak sınıflandırılır. Risk alıcı davranış, belirli bir oranda istenmeyen sonuçların doğma olasılığını yaratan davranış olarak tanımlanmaktadır. Birçok çalışmaya göre, risk alıcı davranış ile suç istatistikleri, geç adolesan ve erken yetişkinlik dönemlerinde pik yapmaktadır. Bizde çalışmamızda suça sürüklenen ancak üniversite eğitimi almayı başaran genç erişkinlerde, suç davranışı ve ilgili faktörlerin yaygınlığını araştırmayı amaçladık. Yöntem: Bu çalışmaya 1. ve 4. sınıf 706 üniversite öğrencisi dahil edilmiştir.

Bulgular: Katılımcılardan \% 15,3’ü en az bir kez suç işlediğini belirtmekte ve suça sürüklenen çocuklarda erkek cinsiyet daha sık görülmektedir. Suça sürüklenen çocuklarda istismara (fiziksel-duygusal-ihmal) uğrama olasılığı ve kendine zarar verme davranışı daha yaygındır.

Sonuç: Suça sürüklenen çocukların önemli bir kısmının erkek olmasının sebebi; daha fazla iş ve sosyal yaşamın içinde olması, kadınların ev dışında geçirdikleri zamanın aile tarafindan daha iyi denetlenmesi ve korunması gibi faktörlerle açıklanabilir. Gelirini yetersiz olarak değerlendirenlerin suça karışma sıklığı, diğer gruba göre yüksektir. Çocukların yoksul bir aile ortamında, yoksul bir çevrede ve mahrumiyet içerisinde yaşamaları; çocukların suç ve problemli davranışlara yönlenebilmelerine neden olabilmektedir. Suça sürüklenen çocuklarda kendine zarar verme davranışı daha yaygındır. Kendine zarar verme davranışının daha düşük gelirlilerde ve belli sosyal gruplarda daha yaygın olduğu gösterilmiş olup suça sürüklenen çocukların yaşadıkları sosyal çevre ve gelir düzeyleriyle ilişkili olduğu düşünülebilir. Sonuç olarak suça sürüklenen çocukların; sıklıkla erkek olduğu, daha düşük gelir grubundan geldiği, kendine zarar verme davranışının daha yaygın olduğu, ailesinde suç geçmişinin daha belirgin olduğu ve çocuk istismarına daha sık uğramış çocuklar olduğu tespit edilmiştir. Suça sürüklenmiş bütün çocuklarda çocuk istismarı ve ihmali ile kendine zarar verme davranışı araştırılmalıdır.

Anahtar sözcükler: Suça sürüklenen çocuk, çocuk istismarı, kendisine zarar verme

\section{INTRODUCTION}

According to the first article of the Convention on the Rights of the Child; any person up to the age of eighteen should be considered as a child ${ }^{1}$. In accordance with Article 6/1-b of the Turkish Penal Code No. 5237, a person who has not completed the age of 18 is attributed as a child ${ }^{2}$. According to Child Protection Law No. 5395, protection is the primary priority for children who are dragged into crime $^{3}$. Crime involvement in children is classified as risk-taking behavior and risk-taking behavior is defined as behavior that creates the possibility of a certain amount of undesirable consequences ${ }^{4}$. Some behaviors that can be defined as risk-taking behavior include excessive alcohol consumption, smoking, substance abuse, high-risk sexual behavior, dangerous driving, being extremely aggressive in human relations, absentism in school, theft, lying, gambling and crime ${ }^{4}$. According to majority of studies, risk taking behavior and crime statistics peak during late adolescence and early adulthood ${ }^{5,6}$. Being able to perceive potentially risky situations in advance and avoiding high risk is seen as one of the most important skills that people can develop ${ }^{4}$. So far, studies on risk-taking behavior and criminal involvement have generally been carried out in developed countries. However, environmental factors of risk-taking behavior such as wars, natural disasters, poverty, low education, epidemic diseases, migration, terrorism and social violence are more common in developing countries 7. In our study, we aimed to investigate the prevalence of crime behavior and related factors in young adults who were dragged into crime but managed to get university education.

\section{MATERIAL AND METHODS}

This study was carried out between Istanbul University and Gaziosmanpaşa University Art and Science Faculty students between 2007-2008. The sample was randomly selected by 1 st and 4 th year students by using power analysis with stratified sampling method. As the criterion for inclusion to the study, it has been determined to be in the 1st and 4th grades of the Faculty of Arts and Sciences. A total of 706 participants were included in the analysis.

Data collection tools: A questionnaire developed by Ögel et al. was used in the research. The questionnaire was filled out by the participants themselves in the classroom. The main topics in the questionnaire form are: socio-demographic information, shelter and family characteristics, health conditions, self-harming behavior, substance use characteristics, friend and environment characteristics, legal and mental conditions and trauma experiences. The questionnaire's inter-interviewer and test-retest reliability were shown previously ${ }^{8}$. Due to the blank answers, $100 \%$ values could not be reached in the tables. Informed consent was obtained from each participant.

This research was partly presented previously ${ }^{9}$.

The data were analyzed using the Epi Info 2000 program. 


\section{RESULTS}

341 of the participants included in our study were male $(48.3 \%)$ and 361 female $(51.1 \%)$. It was seen that 128 participants were under the age of 18, 140 participants were 19 years old, 426 participants were 20 years old and above.

Table 1: The responses of the participants to the questions about whether they commit a crime and the parameters questioned about it

\begin{tabular}{|l|c|c|c|c|c|}
\hline & No & Only once & $2-3$ times & $4-5$ times & More than 5 \\
\hline $\begin{array}{l}\text { Have you commited any } \\
\text { crime? }\end{array}$ & $598(84,7 \%)$ & $77(10,9 \%)$ & $20(2,8 \%)$ & $5(0.7 \%)$ & $6(0,8 \%)$ \\
\hline $\begin{array}{l}\text { Have you testified to the } \\
\text { legal authorities because } \\
\text { of the crime claim? }\end{array}$ & $619(87,7 \%)$ & $41(5,8 \%)$ & $16(2,3 \%)$ & $4(0,6 \%)$ & $1(0,1 \%)$ \\
\hline $\begin{array}{l}\text { Have you ever stolen } \\
\text { something? }\end{array}$ & $564(79,9 \%)$ & $69(9,8 \%)$ & $36(5,1 \%)$ & $3(0,4 \%)$ & $7(1 \%)$ \\
\hline $\begin{array}{l}\text { Have you been in prison or } \\
\text { correctional facility? }\end{array}$ & $677(95,9 \%)$ & $2(0,3 \%)$ & - & $1(0,1 \%)$ & - \\
\hline $\begin{array}{l}\text { Did your mother or father } \\
\text { remain in prison? }\end{array}$ & $640(90,7 \%)$ & $37(5,2 \%)$ & $4(0,6 \%)$ & $1(0,1 \%)$ & - \\
\hline $\begin{array}{l}\text { Are there any prisoners } \\
\text { staying in close relatives? }\end{array}$ & $426(60,3 \%)$ & $160(22,7 \%)$ & $83(11,8 \%)$ & $4(0,6 \%)$ & $7(1 \%)$ \\
\hline
\end{tabular}

While $598(84.7 \%)$ of the participants stated that they did not take any action that could be considered a crime during their lifetime, 108 $(15.3 \%)$ stated that they committed a crime at least once. (Table 1). While $13.8 \%$ of the children dragged into crime have a mother or father's criminal history, the same rate is $5 \%$ in the other group.

Table 2: Answers of 87 of 108 participants who stated that they committed a crime related to crime parameters

\begin{tabular}{|l|c|c|c|c|c|c|}
\hline & No & Only once & $2-3$ times & $4-5$ times & More than5 & $\mathrm{p}$ \\
\hline $\begin{array}{l}\text { Have you testified to the legal } \\
\text { authorities because of the crime } \\
\text { claim? }\end{array}$ & $56(64,4 \%)$ & $17(19,5 \%)$ & $11(12,6 \%)$ & $2(2,3 \%)$ & $1(1,1 \%)$ & 0,001 \\
\hline $\begin{array}{l}\text { Have you ever stolen } \\
\text { something? }\end{array}$ & $54(62,8 \%)$ & $17(19,8 \%)$ & $10(11,6 \%)$ & $2(2,3 \%)$ & $3(3,5 \%)$ & 0,001 \\
\hline $\begin{array}{l}\text { Have you been in prison or } \\
\text { correctional facility? }\end{array}$ & $83(96,5 \%)$ & $2(2,3 \%)$ & - & $1(1,2 \%)$ & - & 0,001 \\
\hline $\begin{array}{l}\text { Did your mother or father } \\
\text { remain in prison? }\end{array}$ & $5(86,2 \%)$ & $9(10,3 \%)$ & $2(2,4 \%)$ & $1(1,1 \%)$ & - & 0,001 \\
\hline $\begin{array}{l}\text { Are there any prisoners staying } \\
\text { in close relatives? }\end{array}$ & $41(47,1 \%)$ & $22(25,4 \%)$ & $17(19,5 \%)$ & $3(3,4 \%)$ & $4(4,6 \%)$ & 0,001 \\
\hline
\end{tabular}

Considering the responses of 87 of 108 children who stated that they were dragged into crime, 87 of them answered the questions about the crime parameters, $64.4 \%$ of them were not questioned by the legal authorities and did not make any statements. The answers to the question of whether you have stolen something are similarly dispersed. There were only 3 participants stayed in the correction house (Table 2). 5\% of those who declare that they have not committed a crime have a parental history of being in prison. Bu oranlar, suç işlediğini ifade edenler için sırasıyla $\% 13,8$ ve $\% 52,9$ 'dur (Tablo 2). This rate is $13.8 \%$ for those who state that they have committed a crime (Table 2). 
Table 3: Criminal involvement and comparison of certain demographic data

\begin{tabular}{|l|l|c|c|c|}
\hline & & Not involved in crime & At least once involved in crime & $\mathrm{p}$ \\
\hline & Male & $266(44,6 \%)$ & $75(71,4 \%)$ & 0,001 \\
\hline & Female & $331(55,4 \%)$ & $30(28,6 \%)$ & 0,78 \\
\hline Place of birth & City & $273(45,9 \%)$ & $46(44,2 \%)$ & \\
\hline & District & $228(38,3 \%)$ & $40(38,5 \%)$ & \\
\hline & Municipality & $19(3,2 \%)$ & $2(1,9 \%)$ & \\
\hline Income & Village & $75(12,6 \%)$ & $76(15,4 \%)$ & 0,001 \\
\hline & Enough & $483(81,1 \%)$ & $33(68,3 \%)$ & 0,61 \\
\hline Home ownership & Not enough & $113(18,9 \%)$ & $87(31,7 \%)$ & \\
\hline
\end{tabular}

Male gender is significantly more frequent in children dragged into crime (Table 3). The frequency of the group who defined their income as "inadequate" was found to be significantly high in crime $(\mathrm{p}<0.001)$.
"If you have committed any crime, how old was this the first time?" 16 of the participants (14.8\%) aged 7-9, $18(16.7 \%)$ aged 10-12, $15(13.9 \%)$ aged $13-15$ and 23 of them (21.3\%) responded as 16 and over. 36 participants did not answer this question.

Table 4: Comparison of Crime and Child Abuse and Neglect

\begin{tabular}{|l|c|c|c|}
\hline & Not involved in crime & At least once involved in crime & P \\
\hline Physical abuse & $194(34,6 \%)$ & $41(56,2 \%)$ & 0,001 \\
\hline Sexual abuse & $102(18,2 \%)$ & $17(23 \%)$ & 0,32 \\
\hline Emotional abuse & $259(45,4 \%)$ & $52(65 \%)$ & 0,001 \\
\hline Neglect & $393(69,9 \%)$ & $65(82,3 \%)$ & 0,02 \\
\hline
\end{tabular}

The probability of physical and emotional abuse and being neglected was found to be significantly more frequent children who are dragged into crime.
In terms of sexual abuse, no significant difference was found between the child dragged into crime and the group not dragged. (Table 4)

Table 5: Comparison of crime involvement and self-harm behavior*

\begin{tabular}{|l|c|c|c|}
\hline & Not involved in crime & At least once involved in crime & $\mathrm{p}$ \\
\hline Self-harm behavior & $81(14,5 \%)$ & $27(25 \%)$ & 0,01 \\
\hline Suicidal ideation & $66(11,2 \%)$ & $14(15,9 \%)$ & 0,21 \\
\hline Suicide attempt & $39(6,6 \%)$ & $7(7,8 \%)$ & 0,65 \\
\hline
\end{tabular}

* Due to the answers left blank, $100 \%$ values could not be reached in all titles.

Self-harming behavior can manifest as cutting various parts of the body, extinguishing cigarettes, or amputation in the end organs. In our study, it was found that self-harming behavior was significantly more frequent in children who were dragged into crime (Table 5). On the other hand, no difference was found in terms of suicidal ideation or attempt.

\section{DISCUSSION}

In our study, we aimed to investigate the prevalence of criminal behavior and related factors in young adults who were dragged into crime but managed to receive university education. According to our results, $15.3 \%$ of the respondents stated that they committed a crime at least once and most often they committed this crime when they were over the age of 16 .

The most important limitation of our study is that its method is cross-sectional. For this reason, the current statements of individuals were taken as basis, but the crimes they committed could not be evaluated impartially. On the other hand, the strengths of the study are the fact that it was collected in a university in two different regions and the use of a valid and reliable data form.

In our study, it was shown that a significant part of the children who were dragged into crime were men. Similar gender distribution was obtained in studies conducted in our country ${ }^{10,11}$. The male dominance is explained by factors such as the fact 
that men are in more business and social life, and that the time spent by women outside the home is better controlled and protected by the family ${ }^{11}$.

Family crime history is also an important factor. In our study, it was revealed that there was a crime history of the mother / father at a rate of $13.8 \%$ in the group of children dragged into crime. In children who are dragged into crime, the rates of crime history among relatives are even higher. It is known that the increase in the number of individuals held in prisons will have negative effects on the society (and the individual) by causing damage to social relations and long-term changes in life ${ }^{12}$. Again in the studies conducted in our country, attention was drawn to the importance of the criminal history in the family ${ }^{10}$.

In our study, it was observed that those who expressed their income as inadequate had a high frequency of involvement in crime. It has been reported that children living in a poor family environment, in a poor environment and deprivation may cause children to be directed to criminal and problematic behaviors ${ }^{13}$.

In our study, physical and emotional abuse and neglect were common in children who were dragged into crime. In our study, all kinds of abuse among children who are dragged into crime are higher than the studies conducted in our country. For example, in a study conducted in our country in 2005, sexual abuse in childhood was $2.5 \%$, physical and emotional abuse was $8.9 \%$ and neglect was $33.9 \%{ }^{14}$. In another study conducted in our country, higher values were obtained, neglect $16.5 \%$, emotional abuse $15.9 \%$, physical abuse $13.5 \%$ and sexual abuse $10.7 \%{ }^{7}$. In fact, it has been shown that there is a relationship between the low income and the reasons that cause child abuse and neglect ${ }^{15,16}$. At this point, it is necessary to investigate the findings of child abuse and neglect in a child dragged into crime. Especially considering that there are more traumatic findings in children who experience different types of abuse together than in children who have a single type of abuse, it becomes even more important ${ }^{17}$.

In a study on children living in the Chinese countryside; It has been determined that the rate of physical abuse is $49.7 \%$ in children, $51.6 \%$ in people with a family history of migration, and $61 \%$ in people with a family history of divorce. In the same study, the rate of being subjected to any sexual abuse was $11 \%, 13.3 \%$ for those with a family history of migration and $24.8 \%$ for those with a family history of divorce or living separately ${ }^{18}$. In our study, the rates of exposure to any type of abuse and the history of any person in his family staying in prison for those involved in crime; we found that it was higher than those who did not commit crime. When we compare the results we obtained with other studies; It is necessary to investigate the history of childhood abuse and familial risk factors in people who are involved in crime.

Another finding in our study is that self-harming behavior is found at a rate of $14.5 \%$ in participants without a crime story. Similar rates were also obtained in previous studies in our country ${ }^{7}$. However, self-harming behavior is more common in children who are dragged into crime. Self-harm behavior has been shown to be more common in lower-income people and in certain social groups 19. Therefore, it can be thought that this data we obtained is related to the social environment and income levels of children who are dragged into crime. Favazza et al. Reported that at least some of the children who came in this situation should not be underestimated by saying personality disorder and treatment may be needed ${ }^{20}$. On the other hand, it was determined that suicidal ideation and suicide attempt did not differ between groups in our study.

As a result, the characteristics of children dragged into crime; often male, had a lower income group, self-harming behavior was more common, family history of crime was more prominent, and experienced child abuse more frequently. Within the scope of Article 31 of the Turkish Penal Code, physicians are asked to evaluate whether the ability of children who have completed the age of twelve and who have not completed the age of fifteen to develop the ability to perceive the legal meaning and consequences of the crime committed and to direct their behavior. Physicians are not asked to evaluate, since those under the age of twelve do not have criminal responsibility. Children who have completed the age of fifteen but have not completed the age of eighteen are subject to a reduced sentence for their sentence, and in cases where there is no mental illness, physicians are not asked for an evaluation ${ }^{2}$. Child abuse and neglect and self-harming behavior should be sought in all children who are involved in crime.

\section{REFERENCES}

1. Çocuk Hakları Sözleşmesi. Resmi Gazete. 27 Ocak 1995. Say1: 22184.

2. Türk Ceza Kanunu. Türkiye Büyük Millet Meclisi. Kabul tarihi: 26.09.2004. Kanun no: 5237.

3. Çocuk Koruma Kanunu. Türkiye Büyük Millet Meclisi. Kabul tarihi: 3.7.2005. Kanun no: 5395. 
4. Boyer Ty W. The development of risk-taking: A multi-perspective review. Developmental Review. 2006;26:291-345.

5. Piquero AR, Farrington DP, Blumstein A. The criminal career paradigm. In M. Tonry (Ed.), Crime and justice: A review of research. Chicago: University of Chicago Press. 2003;30:pp. 359-506.

6. Knust S, Stewart AL. Risk-Taking Behaviour and Criminal Offending: An Investigation of Sensation Seeking and the Eysenck Personality Questionnaire. International Journal of Offender Therapy and Comparative Criminology. 2005;46(5):586-602.

7. Zoroglu SS, Tuzun U, Sar V, Tutkun H, Savas HA, Ozturk M, Alyanak B, Kora ME. Suicide attempt and self-mutilation among Turkish high school students in relation with abuse, neglect and dissociation. Psychiatry Clin Neurosci. 2003 Feb;57(1):119-26.

8. Ögel K, Aksoy A, Liman O, Yücel H, Sorgun E, Polat Z. Sokak çocuklarıyla görüşme formunun güvenilirliği. 39. Ulusal Psikiyatri Kongresi, Antalya, 2003

9. Toprak S, Yıldırım A, Çetin I, Aksu M. Fen Edebiyat Fakültesi Öğrencileri Arasında Risk Alıcı Davranışların Yaygınlığı. 8. Adli Bilimler Kongresi. Kocaeli. 2008.

10. Aksu H, Demirkaya SK, Ozgür BG, Gün B. Aydın ilinde bir yıldaki çocuk ve ergen adli olguların değerlendirilmesi. Anadolu Psikiyatri Derg. 2013;14:369-377.

11. Kurtulus A, Salman N, Gunbet G, Boz B, Cenger CD, Acar K. Denizli İlinde 12-15 Yaş Arasındaki Suça Sürüklenen Çocukların Sosyodemografik Özellikleri. Pamukkale Tip Dergisi 2009;2(1):8-14.
12. Clear TR. The effects of high imprisonment rates on communities. Crime and Justice. 2008;37(1):97-132.

13. Sevgi Çoban. Sosyal Çevrenin Etkilerinin Çocukların Suç Ve Problemli Davranışları İle İlişkileri. Doktora Tezi. Ankara, 2012.

14. Akyuz G, Sar V, Kugu N, Doğan O. Reported childhood trauma, attempted suicide and selfmutilative behavior among women in the general population. Eur Psychiatry. 2005;20:268-73.

15. Nurcombe B. Child sexual abuse I: psychopathology. Aust N Z J Psychiatry. 2000;34:85-91.

16. McCrann D, Lalor K, Katabaro JK. Childhood sexual abuse among university students in Tanzania. Child Abuse Negl. 2006;30:1343-51.

17. Finkelhor D, Ormrod RK, Turner HA. Polyvictimization: A neglected component in child victimization. Child abuse \& neglect. 2007;31(1):7-26.

18. Mengtong C, Ko Ling C. Parental absence, child victimization, and psychological wellbeing in rural china. Child Abuse \& Neglect. 2016;59:45-54.

19. Izutsu T, Shimotsu S, Matsumoto T, Okada T, Kikuchi A, Kojimoto M, Noguchi H, Yoshikawa K. Deliberate self-harm and childhood hyperactivity in junior high school students. European Child \& Adolescent Psychiatry. 2006;15:172-176.

20. Favazza AR. The coming of age of selfmutilation. The Journal of nervous and mental disease. 1998;186(5):259-268. 